\title{
Mahshid Moshiri. Mille ans de poésie persane : les poètes persanophones : à partir de l'apparition du persan jusqu'à présent
}

Ève Feuillebois-Piérunek

\section{(2) OpenEdition \\ 1 Journals}

\section{Édition électronique}

URL : http://journals.openedition.org/abstractairanica/40923

DOI : 10.4000/abstractairanica.40923

ISSN : 1961-960X

Éditeur :

CNRS (UMR 7528 Mondes iraniens et indiens), Éditions de l'IFRI

\section{Édition imprimée}

Date de publication : 1 décembre 2013

ISSN : 0240-8910

\section{Référence électronique}

Ėve Feuillebois-Piérunek, « Mahshid Moshiri. Mille ans de poésie persane : les poètes persanophones à partir de l'apparition du persan jusqu'à présent », Abstracta Iranica [En ligne], Volume 32-33 | 2013, document 414, mis en ligne le 01 juillet 2016, consulté le 26 septembre 2020. URL : http:// journals.openedition.org/abstractairanica/40923; DOI : https://doi.org/10.4000/abstractairanica. 40923

Ce document a été généré automatiquement le 26 septembre 2020.

Tous droits réservés 


\title{
Mahshid Moshiri. Mille ans de poésie persane : les poètes persanophones : à partir de l'apparition du persan jusqu'à présent
}

\author{
Ève Feuillebois-Piérunek
}

\section{RÉFÉRENCE}

Mahshid Moshiri. Mille ans de poésie persane : les poètes persanophones : à partir de l'apparition du persan jusqu'à présent. Paris, L'Harmattan, 2009, 242 p. (Poètes des Cinq Continents)

Ce livre est une petite encyclopédie: après un rapide survol de l'histoire de la littérature persane en une trentaine de pages et la présentation des principaux genres, il contient 555 entrées sur les poètes persanophones. Assurément utile pour les étudiants et les personnes intéressées par cette littérature, il pèche cependant par une translittération très francisée et le caractère parfois anecdotique des notices. Celles-ci, à la manière des classiques tadkere mais de manière beaucoup plus concise, donnent quelques renseignements sur la vie de l'auteur, les titres de ses œuvres et souvent une ou deux citations en traduction. La rédactrice, universitaire et écrivaine, ne manque pas d'érudition, mais reprend malheureusement beaucoup d'informations communément répétées dans les manuels iraniens, mais sujettes à caution, sans faire état des débats en cours sur la question. Ceci ne devrait cependant pas gêner le lecteur soucieux de trouver rapidement une information sur un auteur. 


\section{AUTEURS}

\section{ÈVE FEUILLEBOIS-PIÉRUNEK}

Université Sorbonne Nouvelle-Paris 3, Mondes iranien et indien, Paris 